\title{
Arte y devoción en las cofradías de la iglesia de la Asunción de Barco de Ávila (siglos XIII a XVIII)
}

\author{
Azucena HeRnÁndez PÉREZ \\ Universidad Complutense de Madrid. \\ mariaahe@ucm.es
}

Entregado: $20 / 12 / 12$

Aceptado: 5/5/2013

\section{RESUMEN}

La iglesia de la Asunción de Barco de Ávila contó desde el siglo XIV con un número importante de cofradías y hermandades que promovieron la ejecución de retablos e imágenes que han llegado a nuestros días. El Archivo Histórico Nacional conserva buena parte de la documentación generada por estas organizaciones y su estudio permite conocer detalles de autoría y datación de dichas obras. Se han estudiado los libros de las cofradías de San Severo y San José que han permitido identificar los nombres de un buen número de artistas y artesanos activos en Barco de Ávila en el siglo XVII así como conocer la implicación de las cofradías en la realidad devocional de la sociedad barcense. Los datos más relevantes se refieren a dos retablos, uno de ellos del entallador Juan Gómez y el dorador Miguel Ciprés que aloja hoy la imagen de la Virgen de la Silla (h.1520) atribuida a Felipe Bigarny y el otro, consagrado a San José, obra del entallador Juan del Arenal y los doradores Luis de Tobar y Antonio Fernández de Torres.

Palabras clave: Cofradía de San Severo, Hermandad de San José, iglesia de la Asunción de Barco de Ávila, Juan del Arenal, Miguel Ciprés, Antonio Fernández de Torres, Cristóbal Honorato el Viejo, Luis de Tobar.

\section{Art and Devotion in the Confraternities Established in the Church of the Assumption of Saint Mary in Barco de Avila (13th to 18th Centuries)}

\begin{abstract}
A good number of confraternities and brotherhoods were established in the church of the Assumption of Saint Mary in Barco de Ávila since the fourteenth century. Those devotional organizations were active promoting altarpieces and images. The National Historical Archives keep a good number of documents generated by those confraternities and brotherhoods and their study provides details about authors and dates for pieces which have been anonymous so far. The analysis of the documentation generated by both the Confraternity of Saint Severus and the Brotherhood of Saint Joseph has provided the identities of various artists and craftsmen active in Barco de Ávila in the seventeenth century. Additional interesting information about the devotional life of the society at that time has also emerged. The most relevant data refers to the altarpiece made by Juan Gómez and gilded by Miguel Ciprés which allocates the image of the Virgin and the Child known as "Virgen de la Silla" (ca. 1520) attributed to Felipe Bigarny and the altarpiece made by Juan del Arenal and gilded by Luis de Tobar and Antonio Fernández de Torres, devoted to Saint Joseph.
\end{abstract}

Key words: Confraternity of Saint Severus, Brotherhood of Saint Joseph, church of the Assumption in Barco de Ávila, Juan del Arenal, Miguel Ciprés, Antonio Fernández de Torres, Cristóbal Honorato el Viejo, Luis de Tobar. 
La iglesia de la Asunción de Barco de Ávila, declarada Monumento Histórico-Artístico en 1931, es uno de los mejores ejemplos de la arquitectura religiosa abulense. Se empobreció tras la desamortización de Mendizábal, pero su monumental arquitectura y lo que queda del importante patrimonio que atesoró nos da una idea de su papel relevante mantenido hasta fechas cercanas. Conoció múltiples reformas, como es habitual en toda gran iglesia, y fue enriquecida con innumerables obras de arte.

La iglesia de Barco de Ávila ha contado desde el siglo XIV con un número importante de cofradías y hermandades, unas gremiales y otras abiertas a habitantes de la ciudad. Muchos de los retablos e imágenes que decoran el templo han sido promovidos por dichas cofradías. Se conservan en el Archivo Histórico Nacional un total de doce libros manuscritos de las siguientes cofradías ubicadas en la iglesia:

- Cofradía de la Vera Cruz

- Cofradía del Santísimo Rosario

- Cofradía de las Benditas Ánimas del Purgatorio

- Hermandad de San José

- Cofradía de San Severo

- Cofradía de Santa Apolonia

- Cofradía sacerdotal

Se ha estudiado el contenido de dos de esos doce libros manuscritos que resultan ser fuente de conocimiento de las costumbres devocionales de la sociedad barcense en los siglos XVII a XIX y, lo que es más importante, nos desvelan datos de autoría de algunos de los retablos e imágenes que se conservan en la iglesia.

Los dos libros manuscritos objeto de este trabajo son:

- "Libro de caxa de las quentas y asiento de los gastos y censos que hecharon los oficiales de peine y carda del Señor San Severo desta villa del Varco. Hízose este año. 1628 años"1

- "Libro de la hermandad del Glorioso S. Joseph, Esposo de la Madre de Dios Nuestro Señor que para gloria y honra de su divina Majestad fundaron los dos gremios de los carpinteros y hortelanos el año de 1653. En que están las ordenanzas, cabildos, cuentas y hermanos"

\section{Iglesia de la Asunción de Barco de Ávila}

La iglesia es un edificio monumental y bien conservado cuya construcción fijan los historiadores entre los siglos XII y XV. La ausencia de documentos previos al siglo $\mathrm{XV}$ que informen sobre las fases constructivas de la iglesia y sus fechas, reducen la tarea de la datación al análisis formal y a la hipótesis plausible.

1 AHN, CLERO_SECULAR_REGULAR, Libro 835.

2 AHN, CLERO_SECULAR_REGULAR, Libro 837. 


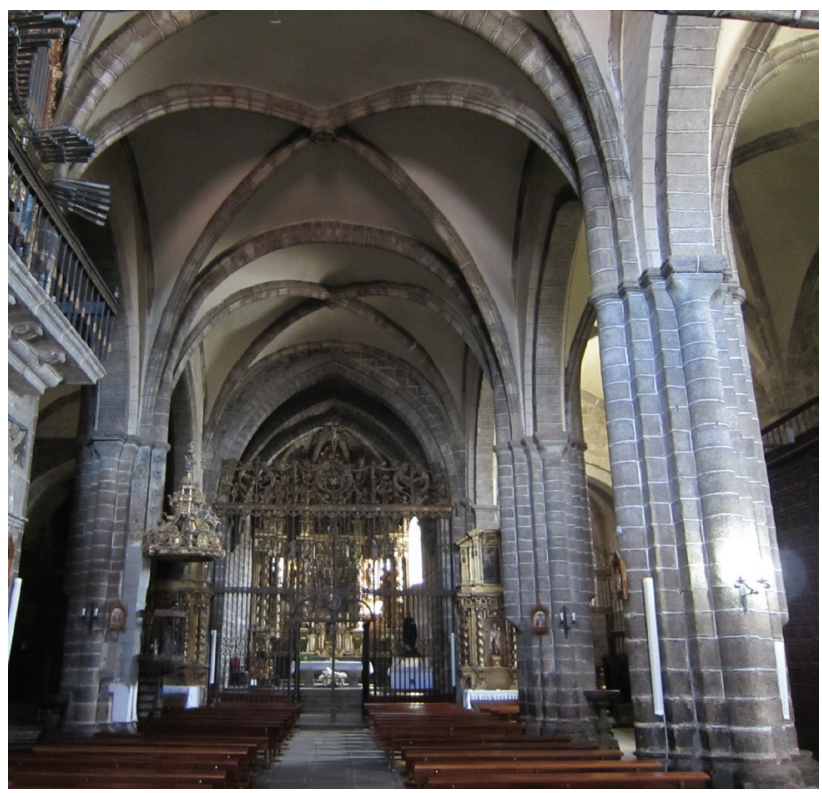

Fig. 1. Interior del templo. Nave principal con pilares cruciformes y columnas adosadas sobre los que voltean arcos fajones de medio punto y bóvedas bícromas de crucería.

Gómez Moreno dató la iglesia a principios del siglo XIV porque "en su fábrica se observan arcaísmos y reminiscencias de la Catedral de Ávila"”. Menciona el recrecimiento de los muros y el paso de cubierta de madera a bóvedas de crucería en piedra y ladrillo pero sin entrar en detalle sobre fechas ni fases.

Gutiérrez Robledo considera que la iglesia tiene dos fases. La primera fase no la fecha exactamente pero, al resaltar sus rasgos románicos, la supone realizada en los siglos XI a XII. A esta fase pertenecen la puerta norte y oeste que han llegado a nosotros y la cubierta original de madera que tuvo la iglesia, considerando que el templo se integraba en una estructura militar defensiva a la que pertenecía la puerta sur y el primer cuerpo de la torre. La segunda fase la data en el siglo XIII y en ella se hizo la cabecera de tres ábsides poligonales, se recrecieron los muros y se voltearon las bóvedas pétreas ${ }^{4}$. Completa su hipótesis indicando que, tras recrecerse la iglesia, se inició la construcción de los dos cuerpos superiores de la torre-vigía, obra que él sitúa en el siglo XIV. En todo caso tuvo que hacerse antes de 1470 pues en esa fecha el castillo de Valdecorneja asumió las funciones de vigilancia y defensa que tuvo previamente la iglesia y ya no hubiera tenido sentido incrementar su altura. A este respecto, González Zymla afirma que el recrecimiento de los muros y las torres del

3 GÓMEZ MORENO, M., Catálogo Monumental de la provincia de Ávila. Edición revisada y preparada por Aurea de la Morena y Teresa Pérez Higuera. Ávila, 1983, p. 335.

4 GUTIÉRREZ ROBLEDO, J. L., El Barco de Ávila: arquitectura y arte. Ávila, 2004, p. 64. 
castillo de Valdecorneja corresponde al tiempo en que pasó a manos de los Álvarez de Toledo a mediados del siglo XIV, si bien esas mejoras debieron acometerse durante el siglo $\mathrm{XV}^{5}$.

A partir de la segunda mitad del siglo XV y hasta el siglo XVIII, se realizaron sucesivas obras de mejora e incremento de la decoración del templo, dadas sus saneadas finanzas.

La planta de la iglesia, dejando a un lado la capilla y sacristías añadidas en los siglos XVI y XVII, responde al tipo arquitectónico de templo de tres naves, la central más ancha que las laterales y sin crucero. Tiene triple cabecera poligonal con el ábside central mayor que los dos laterales y torre de sección cuadrada adosada en el ángulo suroccidental ${ }^{6}$. Los pilares son cruciformes, con columnas adosadas sobre las que voltean arcos formeros doblados y levemente apuntados y arcos fajones de medio punto [Fig.1]. De los capiteles sobre los que voltean los arcos de acceso a los ábsides dice Gómez Moreno: "los arcos ofrecen por capitel zonas entalladas de cabezas, figuras humanas tendidas, animales monstruosos y diablos: todo rudísimo" ". Este carácter rudo asociado a capiteles de clara raigambre románica por su temática, que destaca Gómez Moreno, así como la convivencia de arcos de medio punto y apuntados, se usa como argumento para la datación del edificio.

Sus muros y bóvedas muestran claramente que estamos ante un edificio planteado inicialmente con naves de distinta altura que las actuales y con cubiertas de madera, y que, en un segundo momento, crecieron las naves en altura, se cubrieron con bóvedas bícromas, con nervaduras de piedra y plementos de ladrillo encalados. Las tres naves, de cuatro tramos cada una (el de los pies mayor que los demás para adaptarse a la sección de la torre) se cubrieron a la misma altura, por eso carece de arbotantes. En el interior se hace patente este recrecimiento por las ventanas cegadas, el despiece de los sillares y la ausencia de un sistema arquitectónico coherente de sujeción de una cubierta de piedra. La cabecera poligonal es de transición entre el románico y el gótico, en opinión de Gómez Moreno. Los tres tramos poligonales se cubren con bóvedas de siete paños con nervios que descansan sobre columnas mensuladas en "cul de lampe".

El exterior muestra el carácter fortificado de la iglesia primitiva y el recrecimiento de los muros y los contrafuertes para soportar el cubrimiento abovedado [Fig. 2]. Tanto en el muro norte como en el sur, en lo alto sobresale una cornisa apoyada en modillones sobre la que se alza la zona superior del muro, indicando claramente que estamos ante un cuerpo construido posteriormente ${ }^{8}$. Toda la superficie perimetral está reforzada con potentes contrafuertes prismáticos truncados en su extremo superior y cruzados por tres filas de molduras. El aparejo de sillares de piedra, procedentes de la cantera del prado de la Calera $^{9}$, se dispone en hileras desiguales en altura y deja

5 GONZÁLEZ ZYMLA, H., "Arquitectura militar y urbanismo de frontera en Barco de Ávila”, Revista de Arqueología, 358 (2011), p. 41.

6 GÓMEZ MORENO, M., Op. cit, p. 335.

7 Ibídem, p. 338

8 GUTIÉRREZ ROBLEDO, J.L., Op. cit., p. 66.

9 DE LA FUENTE ARRIMADAS, N., Fisiografía e historia del Barco de Ávila. Edición facsímil del original de 1926 realizada por José Luis Gutiérrez Robledo, Tomo I. Ávila, 1983, p. 197. 


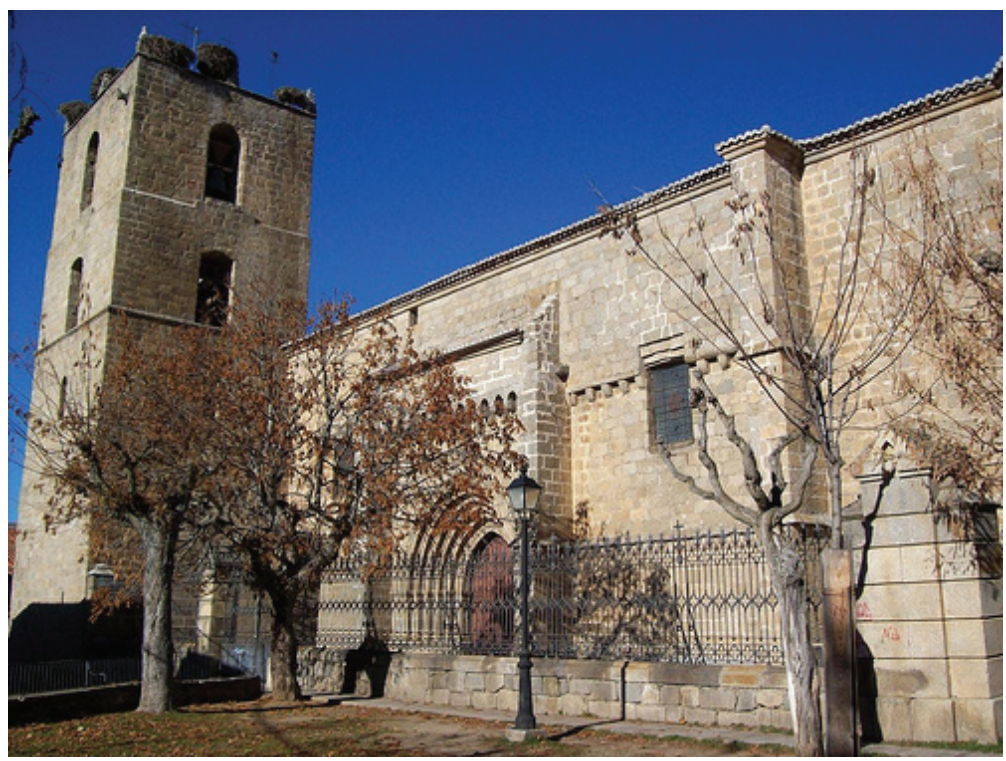

Fig. 2. Vista exterior del costado sur del templo con la portada principal cobijada bajo matacanes y torre de sección cuadrada de tres cuerpos.

ver el cegado de las saeteras y de las almenas que tuvo el templo original. La portada principal estaba defendida por una hilera de matacanes [Fig. 3].

Exteriormente, la cabecera se articula mediante potentes contrafuertes radiales y un zócalo en forma de talud. Las ventanas de las capillas laterales son geminadas y rematadas por un óculo trebolado y las de la capilla mayor son similares pero con un óculo semicircular. Al montar el retablo barroco en el siglo XVII se alteraron las ventanas eliminando el mainel y cerrándose el óculo con ladrillos sobre los que se trazó un esgrafiado en forma de roseta ${ }^{10}$.

La iglesia tiene tres portadas distintas con escasa decoración. La portada sur, que es la principal, presenta seis arquivoltas de baquetones en arco apuntado que descansan sobre columnas adosadas al muro con capiteles de hojas trifoliadas, racimos de vid y un rostro humano considerado una Santa Faz en el ángulo oriental. La portada norte, llamada de "el Lanchado" tiene forma de arco apuntado con tres arquivoltas sobre una moldura sin decoración. Es más arcaizante y no está alineada con la puerta sur ni con la disposición de los pilares interiores. Gutiérrez Robledo considera que esta puerta es la más antigua y perteneció a la primera fase constructiva de la iglesia $^{11}$. La portada oeste está sobreelevada para salvar el desnivel del terreno y se accedía a ella por unas escaleras que no se conservan. El vano se cubre con arco de medio punto con arquivoltas molduradas sobre columnas con capiteles zoomórficos,

10 GUTIÉRREZ ROBLEDO, J.L., Op.cit, p. 65.

11 Ibídem, p. 66. 


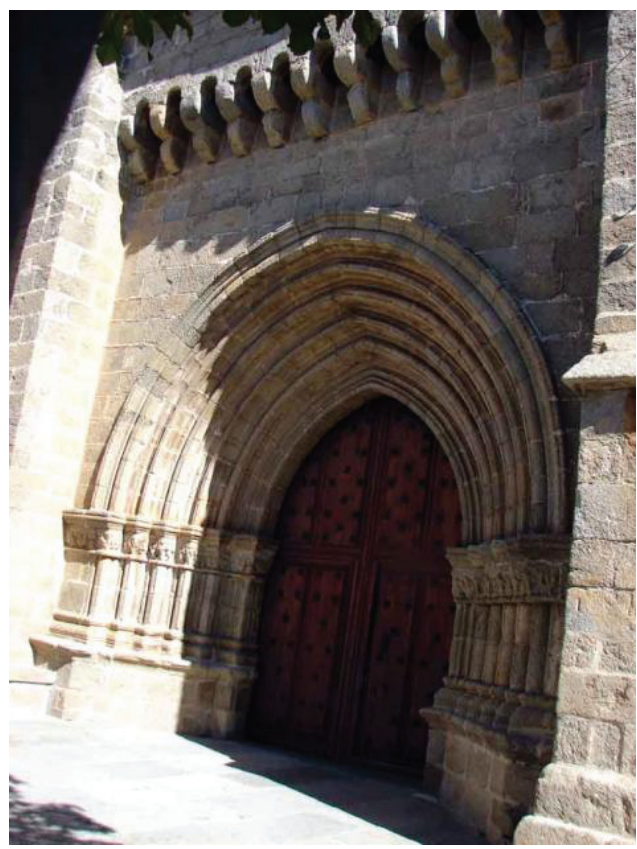

Fig. 3. Portada principal entre contrafuertes con seis arquivoltas y capiteles de hojas trifoliadas.

y está cobijado bajo una bóveda rebajada de perfil escarzano a modo de nártex que se añadió posteriormente, según Gómez Moreno. Sobre la puerta hay dos óculos y una ventana de arco apuntado para dar luz a los pies del templo donde se ubica el coro. La portada está reforzada con dos contrafuertes y el vano que fue la puerta es hoy una ventana. En la parte superior se ve muy bien el recrecido de los muros en la posición que ocupan las gárgolas.

La torre es de sección cuadrada y tiene tres cuerpos. El cuerpo bajo se levanta sobre roca natural, se remata por una cornisa de bolas y se accede a su interior desde el templo. Llega esta escalera hasta un cuerpo que, más que un campanario, parece un cuerpo de guardia con vanos pequeños para vigilancia sobre los cuatro puntos cardinales. En algún momento posterior se superpusieron, sobre la cornisa de bolas, dos cuerpos de campanas rematados en una terraza adornada con pináculos góticos que ya superan la altura del recrecido templo ${ }^{12}$ [Fig. 1]. La torre alcanza así los $25 \mathrm{~m}$ de altura y tiene un más claro papel de vigía y de control del territorio sobre las vías naturales por las que transitaban los ganados trashumantes ${ }^{13}$. Nicolás De la Fuente Arrimadas dice de la torre: "Hay una torre única a un lado de la fachada principal con funciones de culto (campanas), de defensa y de amor propio" 14 . Gómez Moreno

12 Ibidem, p. 68.

13 GONZÁLEZ ZYMLA, H., Op. cit, pp. 40-41.

14 DE LA FUENTE ARRIMADAS, N., Op. cit.p. 200. 
la describe "la maciza torre de tres cuerpos en releje, con cornisa de bolas, arcos ya agudos, ya escarzanos, ya redondos y remate de mezquinas pirámides góticas" 15 .

Desde finales del siglo XV hasta finales del XVII se realizaron obras de ampliación de la iglesia de las que contamos con fuentes documentales ${ }^{16}$.

\section{Las cofradías de la Iglesia de la Asunción de Barco de Ávila}

La hermandad más antigua y más rica de la iglesia de Barco de Ávila fue la cofradía de la Vera Cruz, fundada en 1340. Tenía capilla propia en la antigua iglesia del Santo Espíritu convertida, a finales del siglo XIV, en Casa de la Pasión ${ }^{17}$. Gozaba de grandes rentas, donaciones y derechos de los cofrades, cobrando por asistir a entierros y rezar los Padrenuestros por las almas de los difuntos tras la procesión del Jueves Santo. La cofradía aún existía en 1926 según afirma Nicolás de la Fuente Arrimadas y pertenecían a ella casi todos los vecinos de $\mathrm{Barco}^{18}$. A principios del siglo XX, la cofradía abandonó la Casa de la Pasión y se instaló en la Capilla del Inquisidor de la iglesia de la Asunción ${ }^{19}$.

La imagen del Cristo Negro [Fig. 4] que se venera en la iglesia perteneció a esta cofradía. La obra pertenece al grupo de crucifixus dolorosus que muestran a un Cristo sufriente por todos los suplicios de la Pasión. Este tipo de imágenes ha sido estudiado en profundidad por Ángela Franco Mata y responden a la necesidad de estimular el sentimiento devocional hacia los sufrimientos padecidos por Cristo en su Pasión que surge en el siglo XIV en la Europa bajomedieval ${ }^{20}$. Esta imagen barcense, que Franco Mata fecha entre 1340 y 1360, es un buen ejemplo de los crucifijos góticos dolorosos entre los que destacan el de Santa María im Kapitol de Colonia de 1304, el dévot crucifix de Perpignan de 1307 y ya en España, los de Fisterra (Coruña), Balaguer (Lérida) y Sanlúcar la Mayor (Sevilla) ${ }^{21}$ y los varios que se conservan en iglesias de Valladolid, Palencia, Salamanca, Zamora y Cáceres. Este Cristo Negro de Barco de Ávila, de autor desconocido, es de escuela castellana y Franco Mata lo considera de

15 GÓMEZ MORENO, M., Op. cit., p. 336.

16 GUTIERREZ ROBLEDO, J.L., Op. cit, pp. 64, 72, 73-75, 157, 161. A finales del siglo XV se construyó un coro sobre arco escarzano a los pies de la iglesia. Alrededor de 1506 se construyó la Capilla del Inquisidor adosada al muro norte y a la altura del primer tramo de las naves. En esas mismas fechas se comunicaron los tres ábsides por medio de arcos de medio punto para crear un amplio presbiterio tras las rejas renacentistas. El maestro cantero Juan Gutiérrez comenzó el año 1546 las obras de la antesacristía, sacristía y el túnel en esviaje de conexión entre ésta y el altar mayor además de la escalera de cuerno de carnero que servía de subida a las salas capitulares, hoy museo parroquial. Alrededor de 1663 se desmontó el retablo gótico del altar mayor y se sustituyó por el retablo barroco que ha llegado a nuestros días. En 1769 se construyó un soporte elevado en la nave lateral del Evangelio para colocar el órgano.

17 DE LA FUENTE ARRIMADAS, N., Op. cit., p. 252.

18 Ibídem, p. 159.

19 Ibídem, p. 160.

20 FRANCO MATA, Á., "'Crucifixus dolorosus". Cristo crucificado, el héroe trágico del cristianismo bajomedieval, en el marco de la iconografía pasional, de la liturgia, mística y devociones”, Quintana, 1 (2002), pp. 16-17.

21 Ibídem, p. 29. 


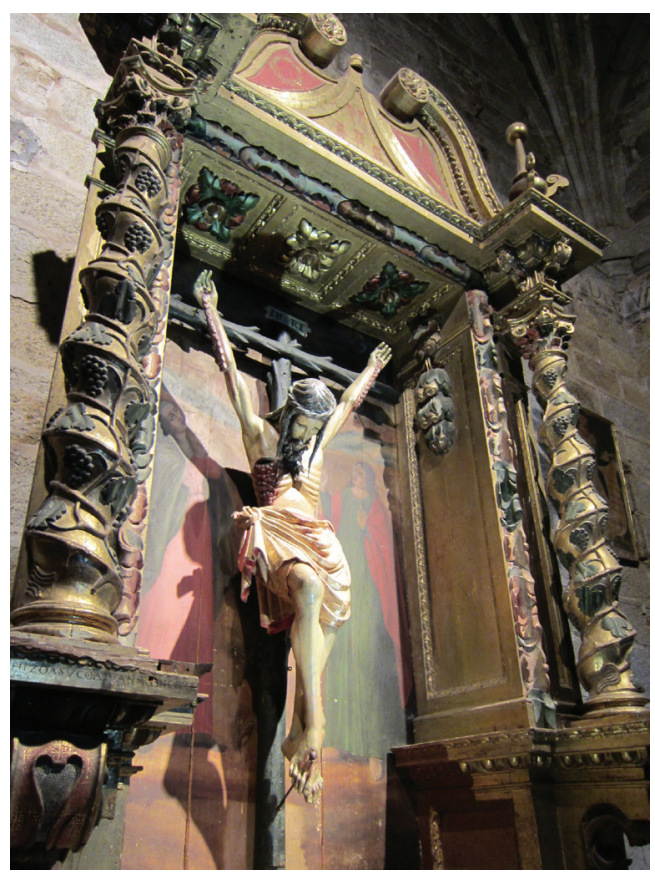

Fig. 4. Cristo Negro, anónimo, 1340-1360.

la misma mano que otro crucifijo anónimo conservado en la iglesia de Santiago de Trujillo (Cáceres).

El Archivo Histórico Nacional guarda dos libros manuscritos pertenecientes a la cofradía de la Vera Cruz:

- "Memoria de los zensos y rentas, posesiones y dotaciones de padrenuestros y abemarías que tiene la cofradía de la Bera Cruz desta villa del Barco, la cual se sacó por el libro antiguo y por las escripturas de zensos" 22 .

- "Libro de cuentas de la cofradía de la Vera Cruz de la villa del Barco. Años 1701 a $1742 " 23$

Adicionalmente se conserva un documento en el Archivo Histórico Nacional que recoge un pleito de la cofradía de la Vera Cruz contra el Estado Español en 1904 por la desamortización de sus bienes ${ }^{24}$.

Si la cofradía de la Vera Cruz fue la más popular y multitudinaria de la villa de Barco de Ávila, la de la aristocracia barcense fue la cofradía del Santísimo Rosario, fundada en 1574 por el teólogo dominico fray Melchor Cano. Esta cofradía se instaló

22 AHN, CLERO_SECULAR_REGULAR, Libro 826.

23 AHN, CLERO_SECULAR_REGULAR, Libro 832.

24 AHN, FC-M ${ }_{-}$HACIENDA,5840-1,EXP.1, Indemnización a cofradía en el Barco de Ávila, 1904-1926. 


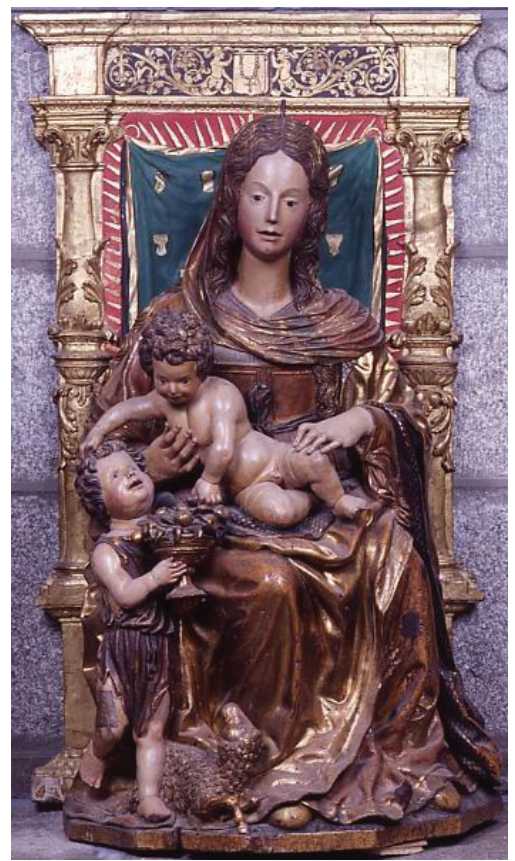

Fig. 5. Virgen de la Silla atribuida a Felipe Bigarny (h.1520).

en el ábside del lado de la Epístola y, en torno a 1660, adquirió la imagen de la Virgen de la Silla [Fig.5] atribuida a Felipe Bigarny y fechada en torno a 1520, para ubicarla en su capilla tras ser desalojada del altar mayor $^{25}$. Es por ello que la imagen se identifica en algunas fuentes documentales como Virgen del Rosario.

De la cofradía de las Benditas Ánimas del Purgatorio se conserva en el Archivo Histórico Nacional el "Libro de la cofradía de las Benditas Animas del Purgatorio sita en la Iglesia Parroquial de $N^{a}$ Sra de la Asunción" ${ }^{26}$. Ha llegado a nuestros días un retablo y un altar de esta cofradía adosado a uno de los muros de la iglesia.

En cuanto a la cofradía de Santa Apolonia, se conservan en el Archivo Histórico Nacional los siguientes libros manuscritos:

- "Libro de cuentas anuales rendidas por los mayordomos de la cofradía de Sta Apolonia, virgen y mártir, fundada en la parroquia del Barco. Años 1688 a 1740”27.

- "Libro de la cofradía de Sta Apolonia instituida en la parroquia de la Asunción de Barco de Avila. Años 1774 a 1794"28.

- S.XVII-XVIII "Instrumentos auténticos de escrituras de propiedades de prados, li-

25 DE LA FUENTE ARRIMADAS, N., Op. cit., p. 213.

26 AHN, CLERO_SECULAR_REGULAR, Libro 820.

27 AHN, CLERO_SECULAR_REGULAR, Libro 834.

28 AHN, CLERO_SECULAR_REGULAR, Libro 825. 
nares, tierras, casas y censos pertenecientes a la cofradía de Sta Apolonia sita en la parroquial del Barco"29.

Otra importante cofradía fue la de San Severo que fue cofradía de los oficiales de "peine y carda", es decir del gremio de tejedores y pañeros y se fundó en 1628 .

El Archivo Histórico Nacional guarda el "Libro de caxa de las quentas y asiento de gastos y censos que hecharon los oficiales de peine y carda del Sr. San Severo desta villa del Varco, hízose este año. 1628 años"31. Este libro se ha analizado y contiene información relativa a la cofradía entre los años 1628 y 1841 que se detallará más adelante.

Por último y no por ello menos importante, la Hermandad de San José fundada en 1653 por los gremios de carpinteros y hortelanos ${ }^{32}$. El Archivo Histórico Nacional guarda dos libros manuscritos de esta cofradía:

- "Libro de la hermandad del Glorioso S. Joseph, Esposo de la Madre de Dios Nuestro Señor que para gloria y honra de su divina Majestad fundaron los dos gremios de los carpinteros y hortelanos el año de 1653. En que están las ordenanzas, cabildos, cuentas y hermanos" 33 . En este libro se han encontrado los detalles económicos relativos a la elaboración de dos retablos con los nombres del ensamblador, escultor, pintor y dorador realizados en la segunda mitad del siglo XVII. Uno de los retablos es el que se encuentra en la capilla del Rosario [Fig.6] alojando ahora a la Virgen de la Silla atribuida a Felipe Bigarny y el otro se encuentra junto al arco de triunfo de la capilla mayor y está dedicado a San José [Fig. 8].

- "Libro de la Hermandad de San José de los gremios de carpinteros y hortelanos, establecida en la parroquia de la Asunción de Barco. Años 1708 a 1834"34.

29 AHN, CLERO_SECULAR_REGULAR, Libro 874.

30 RÉAU, L., Iconografía del arte cristiano, Barcelona, 1997, Tomo 2, vol. 5, pp. 214-215. San Severo de Rávena era un humilde tejedor de lana en esa ciudad, casado y con una hija. Dejó su trabajo un día para asistir a la elección del obispo y se ocultó humildemente tras una puerta de la iglesia. Una paloma se posó sobre su cabeza señalándole como el obispo que debía ser elegido. La multitud lo maltrató, pero la paloma, obstinadamente, se mantuvo sobre su cabeza. Finalmente los sacerdotes vertieron óleo sobre su cabeza para ungirlo como obispo de Rávena. El culto a San Severo pasó de Rávena al resto de Europa. Es patrono de los tejedores y pañeros y se le representa vestido de obispo con una lanzadera o un peine de cardar de tejedor en la mano en alusión a su oficio y con una paloma posada sobre su hombro en recuerdo de su vocación episcopal.

31 AHN, CLERO_SECULAR_REGULAR, Libro 835.

32 RÉAU, L., Op. cit., Tomo 2, vol. 4, pp. 162 y 166. La condición de carpintero de San José está recogida en el Evangelio de San Mateo (Mt, 13, 53-58) y de ahí su papel de patrono de los trabajadores de la madera: carpinteros, ebanistas y zapadores. No está tan clara la relación de San José con el gremio de hortelanos aunque se considera que la floración de la vara que lleva en su mano, que se recoge en los Evangelios Apócrifos y determinó su elección como esposo de la Virgen, imponiéndose sobre otros candidatos más jóvenes, le convierte en el santo de la devoción del gremio de hortelanos.

33 AHN, CLERO_SECULAR_REGULAR, Libro 837.

34 AHN, CLERO_SECULAR_REGULAR, Libros 821-823. 


\section{Libro de la cofradía de San Severo conservado en el Archivo Histórico Nacional}

El libro manuscrito de la cofradía de San Severo ${ }^{35}$ consta de 569 folios numerados, de los cuales los 437 primeros están escritos y el resto, hasta el folio 569, están en blanco. Al final del libro hay cinco hojas sueltas de un documento notarial en papel timbrado de cuarenta maravedíes con sello del rey Carlos IV, fechadas en 1795 y firmadas ante el obispo de Ávila que da fe de las cuentas de la cofradía durante los años 1789,1790 y 1791 .

El primer folio contiene el título: "Libro de caxa de las quentas y asiento de los gastos y censos que hecharon los oficiales de peine y carda. De Señor San Severo. Desta villa del Varco. Hízose este año. 1628 años."

El libro manuscrito establece que la cofradía se fundó en 1628 por los oficiales de peine y carda, es decir el gremio de tejedores y pañeros de la ciudad. Al frente de la misma se elige cada año un Capitán que es quien responde ante los cofrades de las cuentas de la institución. El resto de miembros, de lo que podríamos llamar la junta de gobierno de la cofradía, se nombran con términos sacados de la jerarquía militar (alférez, sargento, cabo,..).

Así por ejemplo, las cuentas del año 1639 se inician así "En la villa del Barco en ocho días del mes de enero de mil y seiscientos y cuarenta años ante mi el presente escribano y testigos se juntaron los oficiales del oficio de peine y carda como lo tienen de costumbre a tomar cuenta a Domingo Martín de Lacilla capitán que ha sido del dicho oficio el año pasado de seiscientos y treinta y nueve señaladamente Juan López Alfaro capitán presente, Pedro de Hureña maese de campo, Bartolomé Sánchez y Juan Rodriguez Borrego alférez, Esteban González y Juan García, sargentos, Antonio Martínez, Diego Sánchez Gil y Julio González Caroponsi y Juan Sevilla, cabos, Simeón Rodríguez, Alonso Ximenez y Alonso Palacios y otros oficiales y asi juntos se hizo en la forma siguiente.[...] Y también se cargan trescientos reales de la ejecución de Jerónimo Sánchez que se entregó a Gascón en la dicha cuenta y quedaron por aprovechamiento. [...]" ${ }^{36}$. Año tras año se registran los ingresos, denominados cargos, y los gastos o descargos, identificados como datta, para finalizar con el balance, siempre con superávit, firmado por el Capitán y los miembros de la junta de gobierno. Intercalados entre los datos contables se incluyen acuerdos tomados por los miembros de la cofradía relativos generalmente a los actos devocionales y piadosos que son el objetivo de este tipo de cofradías.

Destaca el acuerdo tomado el 10 de septiembre de 1640 de "fundar un altar al glorioso San Severo en la iglesia parroquial de nuestra señora de la Asunción de la villa de Barco..[..] como se entra a mano derecha...[... ${ }^{37}$

En cuanto a los acuerdos de naturaleza devocional, a modo de ejemplo se cita el acuerdo fechado en 1763 ante notario que recoge que, en los entierros de los cofrades, se erija, no sólo la imagen del Santo, sino también el Crucificado, un estandarte de tela negra, la cruz del pendón, las insignias y la vara de la cofradía portada por el

35 AHN, CLERO_SECULAR_REGULAR, Libro 835.

36 AHN, CLERO_SECULAR_REGULAR, Libro 835, f. 38r.

37 AHN, CLERO_SECULAR_REGULAR, Libro 835, f. $42 \mathrm{v}$. 
Capitán. El texto nos informa de cómo era la vara: "se halla gravada, en lo superior, la imagen de $N^{a}$ Sra de la Concepción que se venera en el altar del santo y el Señor San Severo" 38 .

La última información que registra el libro es la visita del obispo de Ávila en 1830 donde indica haber supervisado las cuentas de los años 1789,1790 y 1791. Indica también no encontrar las cuentas desde 1792 en adelante y se pregunta quién está percibiendo las rentas y limosnas que ingresaba la cofradía que en este año de 1830 ya estaba disuelta. El documento notarial desvela las dificultades económicas que sufrió la cofradía en 1790 por falta de pago de los cofrades y ciertas irregularidades económicas imputadas al Capitán.

\section{Análisis de los datos económicos de la Cofradía de San Severo}

Los ingresos de la cofradía se obtienen principalmente por la cuota que pagan los cofrades (se registra como limosna de los cofrades) que supone el $60 \%$ de los ingresos y el $40 \%$ restante por censos de prados y casas.

La evolución de los ingresos desde mediados del siglo XVII a finales del XVIII es de un descenso contenido con algunas bajadas puntuales fuertes. Por ejemplo, el total de ingresos en 1640 es de 2426 reales de vellón, pasando en 1715 a 1200 reales, en 1730 es de 1500 reales, 1750 es de 1300, en 1772 baja a 961 reales, en 1775 ya está en 1352 reales y, en el último año con cuentas, el 1789, baja a 672 reales (debido a una caída a la mitad del número de cofrades) con unos gastos de 966 y por tanto unas pérdidas de 294 reales. Los documentos notariales de 1795 se hacen eco de la bancarrota de la cofradía.

El número de cofrades que pagaban la cuota (algunos años se indica la expulsión de cofrades por su morosidad pero otros años no se dice nada, el número de morosos oscila entre 20 y 40) estaba entre los 123 y los 194 . Hay oscilaciones de hasta un $30 \%$ en el número de cofrades que pagan. La gráfica de evolución del número de cofrades que abonan su cuota entre los años 1715 y 1789 es:

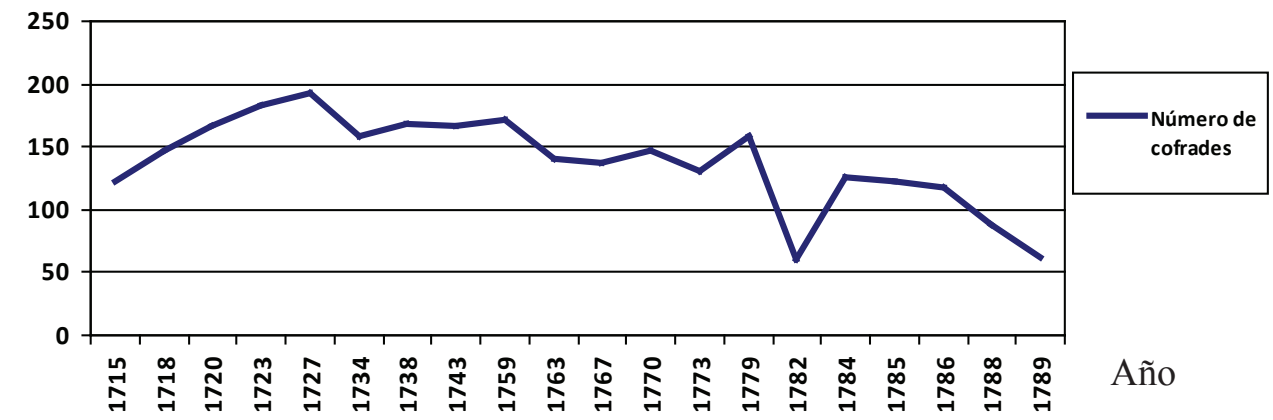

38 AHN, CLERO_SECULAR_REGULAR, Libro 835, f. 330r. 
En cuanto a los gastos, la partida más importante en cada año es la cera para las velas que alumbran siempre el altar del santo (entre un 30\% y un $40 \%$ del total de gastos). Hay también gastos notariales por pleitos relativos a los censos que generan parte de los ingresos de la cofradía y gastos de mantenimiento de dichas propiedades sujetas a censos.

Desde el año 1715 se registra todos los años un gasto por la Función del día de la Minerva que se celebraba el tercer domingo de abril de cada año. Esta función precisaba la contratación de músicos y el pago de una cantidad al Cabildo de la iglesia de la Asunción. Otro gasto, registrado tras este, y denominado Colación de la Minerva detalla la compra de vino y bizcochos para un refrigerio de cofrades y músicos. Todas las cofradías de la iglesia debían contribuir económicamente a la gran celebración litúrgica, seguida de un refrigerio, en honor del Santísimo Sacramento que se celebraba el tercer domingo de abril. El nombre de Minerva está en relación con la cofradía del Santísimo Sacramento de la iglesia de Santa María Sopra Minerva de Roma que contaba con indulgencias plenarias y parciales para los participantes en este tipo de celebraciones sacramentales desde mediados del siglo XVI ${ }^{39}$. A título de ejemplo se citan gastos relativos a esta celebración de la Minerva:

- Las cuentas de 1715 registran un gasto de cuarenta y cinco reales y medio (45 reales y 16 maravedíes) "de los derechos de Minerba en el mes de abril de cada año en la Cofradía según su estatuto, cursado recibo del sacristán mayor" "40.

- Las cuentas de 1753 registran un gasto de 47 reales y medio (47 reales y 16 maravedíes) para los señores del Cabildo y los músicos de la función de la Minerva y 30 ducados "del refresco que se distribuyó entre los cofrades y músicos el día de la Minerva" ${ }^{41}$

- Se conserva el recibo de fecha 20 de abril de 1779, firmado por el sacristán mayor de la iglesia de la Asunción, D. Francisco López González, donde se detallan los gastos relativos a "minerva que hace la cofradía del Señor San Severo en este mes de abril de 1779:

\begin{tabular}{|c|c|}
\hline$\checkmark$ & Santo Cavildo................................ 12 reales \\
\hline$\checkmark$ & Vestuario, incienso y carbón................ 5 reales \\
\hline$\checkmark$ & Sacristanes mayores..................... 6 reales \\
\hline$\checkmark$ & Organista..................................4 4 reales \\
\hline$\checkmark$ & Crucero y perteguero.......................... 3 reales \\
\hline$\checkmark$ & Monaguillos y entonadores................ 3 reales y 16 maravedies \\
\hline$\checkmark$ & Campaneros................................ 4 reales \\
\hline
\end{tabular}

También figuran todos los años, desde 1715, los gastos relativos a la fiesta de San Severo, patrón de la cofradía que se celebraba el segundo domingo de noviembre. El apunte detalla que los gastos son para músicos, capas y vestuario y a modo de ejemplo, en las cuentas del año 1754 , la suma asciende a 94 reales. ${ }^{42}$

\footnotetext{
39 GONZÁLEZ ZYMLA, H., Historia y arte en el real monasterio cisterciense de Santa María de Piedra, Tesis doctoral de la UCM, Madrid, 2011, Tomo III, p. 194.

40 AHN, CLERO SECULAR REGULAR, Libro 835, f. $71 \mathrm{r}$.

41 AHN, CLERO_SECULAR_REGULAR, Libro 835, f. $281 \mathrm{r}$.

42 AHN, CLERO_SECULAR_REGULAR, Libro 835, f. $286 \mathrm{r}$.
} 


\section{Gastos en imágenes y objetos suntuarios}

Las partidas de gastos relacionadas con imágenes, objetos litúrgicos, orfebrería y textiles se detallan a continuación:

- En las cuentas de 1722, siendo Capitán de la cofradía de peine y carda de San Severo D. Manuel Antúnez, vecino de la villa del Barco, se registra un pago de 820 reales por "el estandarte de damasco con la cruz de plata y escudos, ambas efigies de $N^{a} \mathrm{Sra}$ de la Concepción y el glorioso San Severo" 43.

- En las cuentas de 1723, siendo Capitán D. Joseph García, vecino de la villa del Barco, se registra un pago de 10 reales a "Manuel Vidal, platero, por la compostura que hizo a la cruz de plata del pendón de la cofradía"44.

- En las cuentas de 1748, siendo Capitán D. Francisco Antonio Francés, se recoge un gasto de 16 reales "de la compostura de las andas y el báculo del Santo que estaban echos pedazos" 45 .

- En las cuentas de 1750, siendo Capitán de la cofradía D. Jacinto Martín, se recoge un gasto de 42 reales y 22 maravedíes "que pago a Joseph Pardo, vecino de la villa de Villafranca, de haber fabricado el báculo y paloma del Santo y del lucimiento de la pintura y dorado" "46

- En las cuentas de 1752 siendo Capitán de la cofradía D. Juan Rodríguez se recoge un gasto de 16 reales "que pago a Francisco Jiménez platero de la compostura de plata del pendón de la cofradía" 47 .

- En las cuentas de 1760, siendo Capitán de la cofradía D. Lorenzo Francés, se recoge un gasto de 18 reales "que costó componer la cruz de plata por averse quebrado" 48 .

En conclusión, el libro de esta cofradía de San Severo, nos proporciona los nombres de algunos artistas/artesanos activos en Barco de Ávila en el siglo XVIII: los plateros Manuel Vidal, activo en 1723 y Francisco Jiménez, activo en 1752 y el escultor y pintor Joseph Pardo, natural de Villafranca, activo en 1750.

\section{Libro de la Hermandad de San José conservado en el Archivo Histórico Nacional}

El libro de la Hermandad de San José ${ }^{49}$ es un manuscrito de 284 páginas en bastante mal estado que recoge datos de esta cofradía desde su fundación en 1653 hasta el año 1705. El primer folio contiene el título: "Libro de la hermandad del Glorioso S. Joseph, Esposo de la Madre de Dios Nuestro Señor que para gloria y honra de su divina Majestad fundaron los dos gremios de los carpinteros y hortelanos el año de 1653.

43 AHN, CLERO_SECULAR_REGULAR, Libro 835, f. 108r.

44 AHN, CLERO SECULAR REGULAR, Libro 835, f. 113r.

45 AHN, CLERO SECULAR REGULAR, Libro 835, f. 253r.

46 AHN, CLERO SECULAR REGULAR, Libro 835, f. 263 r.

47 AHN, CLERO SECULAR REGULAR, Libro 835, f. 275r.

48 AHN, CLERO_SECULAR_REGULAR, Libro 835, f. 319r.

49 AHN CLERO_SECULAR_REGULAR, Libro 837. 
En que están las ordenanzas, cabildos, cuentas y hermanos". La primera letra, una L mayúscula presenta decoración vegetal en color rojo. El resto de las letras son grandes y bien rotuladas. Tras una greca geométrica se inicia el texto propiamente dicho.

Los folios 1 a 24 recogen acuerdos tomados en las juntas celebradas por los hermanos cofrades representantes de los gremios de los carpinteros y de los hortelanos a partes iguales, los folios 24 a 34 recogen asientos contables de la cofradía y los siguientes, del 34 al 63, faltan. Los folios 64 a 69 recogen las ordenanzas de la cofradía y los folios 70 a 100 contienen las listas de los hermanos cofrades con nombres y apellidos indicando cuándo entran a formar parte de la cofradía, cuándo mueren y cuándo se van (si se van). En el folio 100 se inician formalmente las quentas de la cofradía desde el año 1654 hasta 1705, llegando así hasta el final del manuscrito con la lista de Mayordomos, máximo cargo de la cofradía, desde su fundación en 1653 hasta el año 1666 que se recoge en los folios 281 y 282. Los folios 283 y 284 están en blanco.

Todos los acuerdos registrados aparecen firmados por representantes de los gremios de carpinteros y de hortelanos a partes iguales. El primer acuerdo se fecha en 1659 y contiene los detalles sobre cómo deben celebrarse los funerales de los cofra$\operatorname{des}^{50}$.

Es muy relevante el acuerdo firmado el 4 de abril de 1666 entre los representantes de la cofradía y el artista Miguel Ciprés, vecino de Barco de Ávila, por el que se compromete a dorar y enmendar el retablo de San José. Además del acuerdo tomado por la cofradía figura la carta de pago al artista con todos sus detalles.

El contrato detalla todo lo que debe realizar el artista Miguel Ciprés que consiste en dorar el retablo de San José, sustituir la cabeza del Niño Jesús y la peana que están en mal estado y pintar dos cuadros a situar a izquierda y derecha de la imagen: unos Desposorios de la Virgen y San José y una Anunciación, único de los dos cuadros que ha llegado hasta nosotros. Se fija el pago total en 1350 reales y dos arrobas de vino tinto, pagaderos en 4 partes: 600 reales en Pascua Florida, 2 arrobas de vino al empezar a dorar, 400 reales en Pascua del Espíritu Santo y los 300 reales finales el tercer domingo de junio del año en curso en que todo debe estar terminado para la celebración de la fiesta de la Minerva de la Hermandad. Se fija una penalización de 200 reales si no se cumple la fecha de finalización. El texto completo del acuerdo es como sigue:

\section{“ACUERDO: CONCIERTO DE RETABLO}

En cuatro días del mes de abril de mil seiscientos sesenta y seis años. Para haber acuerdo como tenemos de costumbre para las cosas tocantes al servicio de Dios, nos juntamos especialmente Domingo Crespo, carpintero, Juan Questa, carpintero, Juan Yustas, hortelano, Juan Sánchez Bigotes, hortelano, Francisco Bigotes, hortelano, Santiago López, hortelano, Francisco Jiménez de Lacalle, hortelano, Domingo Hernández, hortelano y, por ante mí, Juan Fernández Ribero, secretario nombrado por esta Santa Hermandad de San Joseph y todos juntos, en voz y en nombre de los demás

50 AHN, CLERO_SECULAR_REGULAR, Libro 837, f.3. 
hermanos ausente e impedidos por quien prestaron voz y caución, en la forma del derecho dijeron que ellos tienen convenido y concertado con Miguel Ciprés, pintor y escultor, de dorar el retablo de su hermandad en esta forma. Que el dicho Miguel Ciprés ha de dorar dicho retablo y enmendar los defectos que tuviese a su elección. Poniendo la capa de brocado en mil trescientos y cincuenta reales y que el dicho Miguel Ciprés a de hacer una peana y dorarla donde esté el santo y por tenerla con su talla. Y que por limosna que ha ofrecido, en las basas de la columna y pedestal a de poner dos historias de pintura, a la mano derecha la historia de los Desposorios de la Virgen y San José y a la izquierda la Anunciación. Y además de los susodicho, ha de quitar la cabeza del Niño Jesús y ponerle otra de nuevo de el cultura y barniz, del cual se le ha de dar dos arrobas de vino y así, en esta conformidad estando presente el dicho Miguel Ciprés dijo que aceptaría dicho cabildo a la letra de que se obligaría con su persona y bienes de dorar dicho retablo, enmendar los defectos que tuviere a su elección y poner la capa de brocado del olio y una peana nueva asimismo dorada con su talla en que esté el Santo, hacer dichas historias, poner la cabeza al Niño y todo lo demás referido y que se le ha de dar dichos mil trescientos y cincuenta reales y dos arrobas de vino en esta forma que se le ha de dar al dicho Miguel Ciprés: seiscientos reales hasta Pascua de Flores deste presente año de mil seiscientos sesenta y seis; dos arrobas de vino negro que comience a dorar; y a la Pascua del Espíritu Santo cuatrocientos reales habiendo comenzado a dorar y los restantes para el tercer domingo del mes de junio de este año que es cuando se hace la Minerva que hace esta hermandad, en que ha de estar terminado el dicho retablo. Y no cumpliendo dicho Miguel Ciprés para el tercer domingo de dicho mes de junio de dicho año, ha de perder doscientos reales de todo el concierto rebajándolo de modo que quede en mil ciento y cincuenta y dos arrobas de vino y no más, y cumpliendo todo se le ha de pagar enteramente. Y dichos hermanos obligaron los bienes de dicha hermandad todo pena de ejecución y costas así una parte contra otra por justicias y a su cumplimiento firmaron los que supieron. (Firmas de Miguel Ciprés, del secretario Juan Fernández Ribero, de Santiago López, de Domingo Hernández y de Juan Yustas" ${ }^{51}$.

A continuación se registran las cartas de pago a Miguel Ciprés:

1. Pago a cuenta de 100 reales el 6 de junio de 1666

2. Pago a cuenta de 300 reales (sin fecha)

3. $\quad$ Pago a cuenta de 307 reales y medio el 19 de diciembre de 1666

4. $\quad$ Pago a cuenta de 95 reales el 19 de diciembre de 1666

5. Pago a cuenta de 70 reales el 19 de diciembre de 1666

6. $\quad$ Pago a cuenta de 214 reales el 22 de diciembre de 1666

7. Pago a cuenta de 37 reales el 23 de diciembre de 1666

8. Pago a cuenta de 24 reales ( $\sin$ fecha) queda a deber 202 reales y medio

9. Pago a cuenta de 100 reales y medio ( $\sin$ fecha), queda a deber 102 reales.

El total es de 1350 reales (como se había contratado) aceptando la Hermandad

51 AHN, CLERO_SECULAR_REGULAR, Libro 837, ff. 6v-7. 


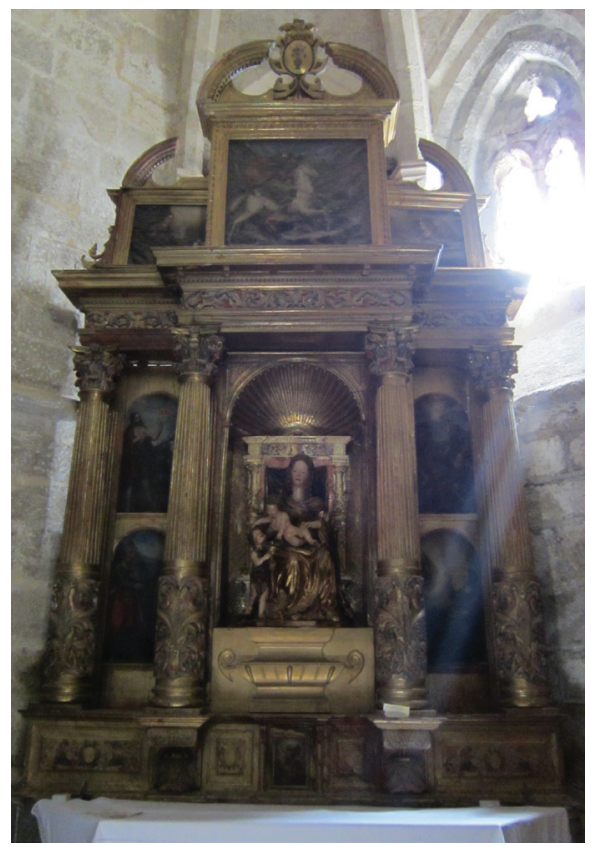

Fig. 6. Retablo de la capilla del Rosario en el ábside lateral de la Epístola de la iglesia de la Asunción. Realizado por el entallador Juan Gómez y el dorador Miguel Ciprés entre 1663 y 1667.

una deuda de 102 reales $^{52}$. En un acuerdo del 13 de marzo de 1667 se reconoce esta deuda y se salda tras reconocer que Miguel Ciprés cumplió lo estipulado en el contrato.

Otro interesante acuerdo es el relativo a la ubicación del retablo del que acabamos de hablar que dio lugar a una controversia entre la Hermandad y el cabildo de la iglesia y que terminó en un pleito que se resolvió mediante donación por parte de la Hermandad de San José del retablo antes mencionado a los representantes de la iglesia y la necesidad de costearse un nuevo retablo para ubicar a su patrón y celebrar sus cultos.

El 20 de septiembre de 1663 se firmó un acuerdo por los representantes de los dos gremios que fundaron la Hermandad de San José, los carpinteros y los hortelanos por el que se comprometen a asumir todos los gastos derivados del pleito por la indeseada ubicación del retablo de San José en la capilla de la Virgen del Rosario. El cabildo de la iglesia no está de acuerdo con esa ubicación y piden a la Hermandad que hagan donación del retablo al vicario, curas y beneficiados para que ellos lo destinen como crean conveniente. A nuestros días ha llegado este retablo [Figs. 6 y 7] alojando la imagen de la Virgen de la Silla atribuida a Felipe Bigarny mientras que la imagen de San José se ubica en otro retablo adosado al arco de triunfo de la capilla mayor

52 AHN, CLERO_SECULAR_REGULAR, Libro 837, f.8. 


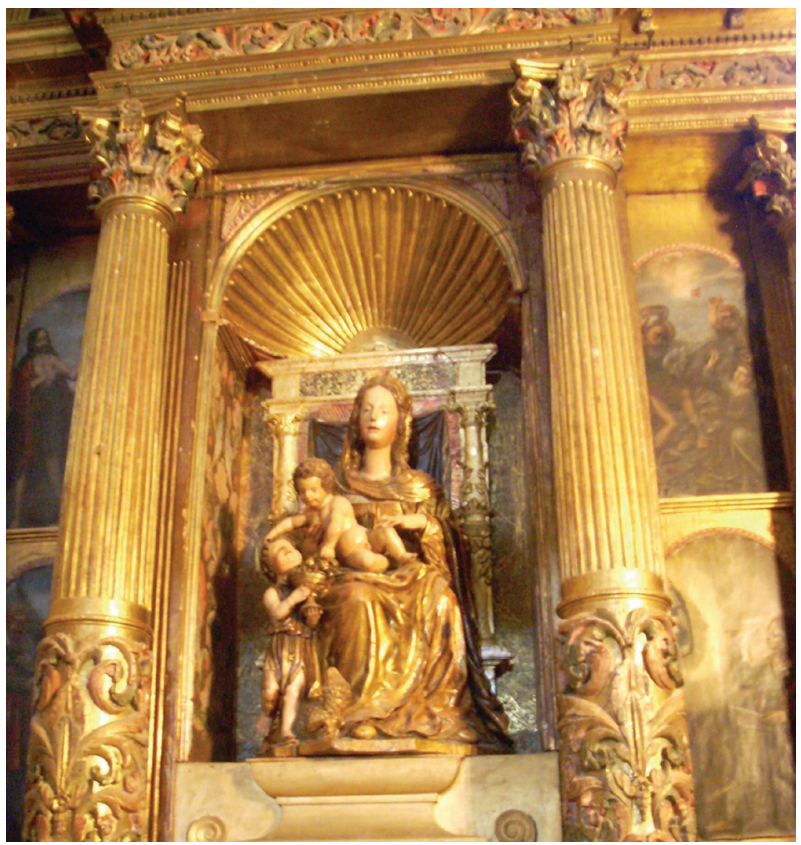

Fig. 7. Detalle del retablo de la capilla del Rosario promovido por la Hermandad de San José que acoge la imagen de la Virgen de la Silla.

[Fig. 8]. Más adelante se detallarán pagos relativos a este segundo y definitivo retablo de San José.

Se transcribe a continuación el texto del acuerdo:

"En la villa del barco a veinte días del mes de septiembre de mil seiscientos sesenta y tres años, estando juntos y congregados los dos gremios de la hermandad de Nuestro Padre San Joseph, carpinteros y hortelanos como lo tienen de costumbre para el servicio de nuestro Señor y aumento de la Santa Hermandad especialmente Juan Cuesta, carpintero, Juan Sanchez Bigotes, hortelano, Mayordomo de dicha Hermandad este presente año, Domingo Crespo y Juan Yustas. Sus antecesores, Juan Francisco, Juan Hernández, Francisco Jiménez Callejas, Domingo Martín Montaner, Domingo Lucas García, Juan García Moracho y Juan Manuel, hermanos de dichos dos gremios y por ante mi Juan Fernández Ribero, secretario de esta Hermandad. Todos juntos unánimes y conformes por sí, en nombre de los demás hermanos enfermos e impedidos y ausentes. Han sido los dichos dos gremios que tienen derecho para hallarse a hacer cabildo como gastos de más que no tienen por quien prestaron voz y caución. El trato grado más en reparto por lo que aqui se contuviera que se hicieron de los bienes propios y rentas que dicha Hermandad tiene espirituales y temporales. Como dijeron que ellos para el servicio al culto de $N^{o}$ Señor San José han hecho un retablo a costa y expensas de los hermanos para que el patriarca santo tuviere con más decencia de la 


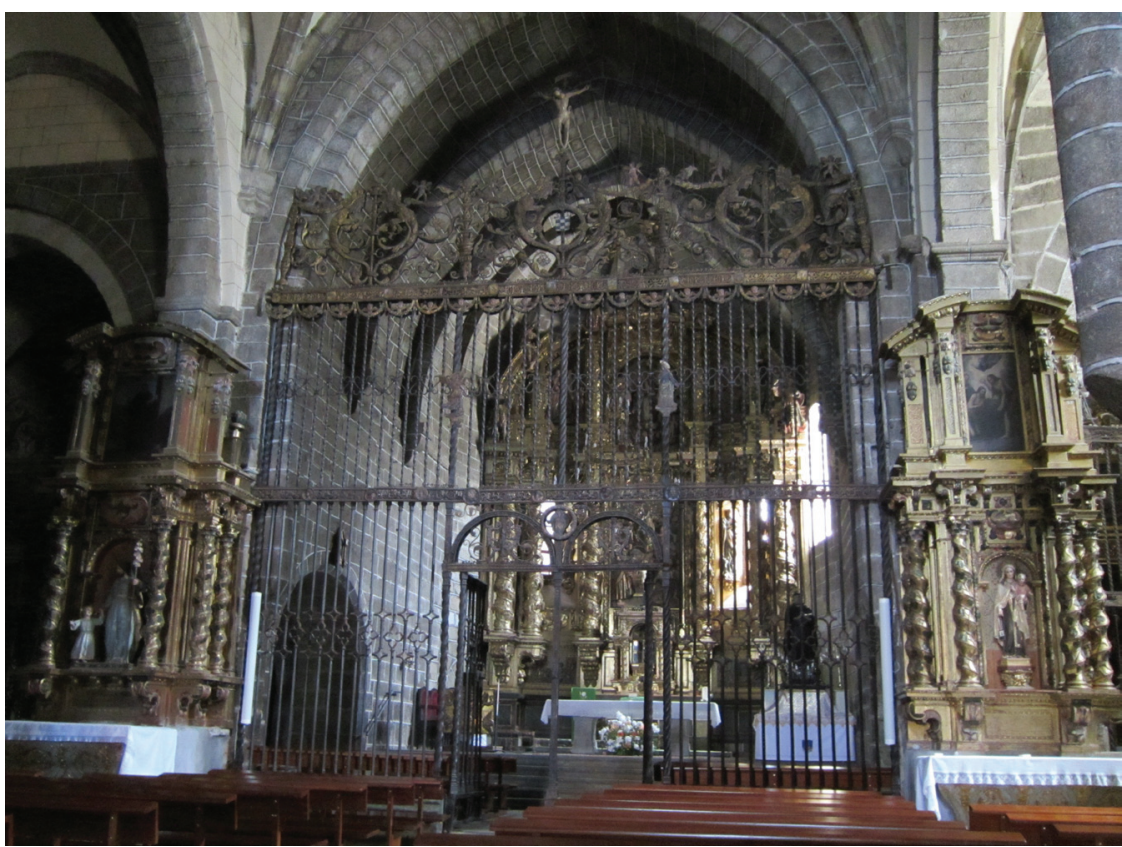

Fig. 8. Vista del acceso a la capilla mayor a cuya izquierda se sitúa el retablo de San José realizado entre 1678 y 1691.

que al presente está en la iglesia de esta dicha Villa. Los señores Justicia han mandado notificar a los dichos Domingo Crespo y Juan Yustas de ciertas penas. No se ponga dicho retablo en la Capilla de $N^{a}$ Sra del Rosario donde está colocado dicho Santo ni en otra parte sin suficiente mandado. Respecto de ser los hermanos pobres y no tener la Hermandad dinero para comprar sitio donde pueda estar dicho Santo..[ilegible].. y otras causas que de ellos los mueven..[ilegible].. dieron comisión en forma a los dichos Juan Cuesta y Juan Fernández Mayordomos presentes para, por sí y en nombre de los demás hermanos hagan donación, cesión y traspasación irrevocable a los señores Vicario, Cura y Beneficiados que al presente son y fueren del Cabildo de la santa iglesia del dicho retablo para que ellos dispongan a su elección poniéndole en la parte y lugar que más bien visto les fuere en dicha iglesia, poniendo en el dicho Santo Patriarca las escrituras de donación necesarias que para ello les dan poder cumplido en bastante forma con las clausulas y firmezas necesarias para su validación y para que no se revocaran en tiempo alguno obligaron a sus personas y bienes muebles y raíces por acuerdo de la hermandad y en base a las competencias y fuerza de la sentencia y así lo dijeron siendo testigos Pedro Fernández Ribero y Ambrosio Fernández Ribero y lo firmaron los que supieron" 53 .

53 AHN, CLERO_SECULAR_REGULAR, Libro 837, ff. 4-5. 
Figuran más acuerdos relativos al funcionamiento interno de la Hermandad y a los nombramientos cada año de los dos Mayordomos (uno del gremio de carpinteros y otro del de hortelanos) que eran la máxima autoridad de la cofradía ${ }^{54}$.

A continuación se incluyen las Ordenanzas de 1775 aprobadas por el obispo de Ávila, miembro del Consejo de Su Majestad el rey Carlos III y por el vicario general de Ávila ${ }^{55}$. Se inician con una oración a la Santísima Trinidad, a la Virgen y a su esposo San José, patrono de la Hermandad. Las ordenanzas recogen, entre otras, las obligaciones relacionadas con la fiesta mayor del santo el 19 de Marzo (por ejemplo, las hachas encendidas que hay que portar en la procesión), las misas por los cofrades difuntos y las velas que hay que tener encendidas en el altar del santo. La Hermandad se rige por dos Mayordomos elegidos cada año (uno por los carpinteros y otro por los hortelanos) y por los dos Mayordomos previos. Se fijan las cuotas de entrada a la Hermandad (4 ducados para los casados y 2 ducados para solteros y viudas) así como las cuotas semanales que son de 8 maravedíes para cada cofrade. Tras las ordenanzas se registran todos los nombres de los cofrades desde 1653 hasta 1708 indicando al margen, entre otros datos, cuándo fallecen y cuánto pagan ${ }^{56}$.

\section{Datos económicos de la Hermandad de San José}

En esta parte del manuscrito se detallan los ingresos y gastos en los que incurre la Hermandad siendo los más relevantes los relativos a los dos retablos que costearon en la segunda mitad del siglo XVII. La fuente principal de ingresos son las cuotas de los hermanos, que suponen la mitad del total de ingresos, la otra mitad la aportan los censos.

Las primeras cuentas recogidas en este libro son las del año de la fundación de la Hermandad, 1653, aprobadas en abril de 1654. Los ingresos totales son de 36675 maravedíes (1078 reales y 23 maravedíes; 1 real $=34$ maravedíes) y los gastos de 29126 maravedíes (856 reales y 22 maravedíes), lo que denota una situación económica saneada. La mayor partida de ingresos corresponde a las cuotas de los hermanos cofrades, y la más alta de gastos es la de cera para las velas. ${ }^{57}$. En estas cuentas de 1654, se recoge un pago de 200 reales "al escultor" pero no detalla ni el nombre del artista ni en concepto de qué58.

En las cuentas del año 1655 vuelven a figurar pagos al escultor y en este caso figura el nombre, Cristóbal Onorato (u Honorato), así como la obra que está realizando "la echura de San Joseph" y la cantidad que se le paga en este año: 28934 maravedíes, es decir 851 reales $^{59}$. Este escultor, identificado por la historiografía,

\footnotetext{
54 AHN, CLERO_SECULAR_REGULAR, Libro 837, ff. 27-28.

55 AHN, CLERO SECULAR REGULAR, Libro 837, ff. 64-69.

56 AHN, CLERO SECULAR REGULAR, Libro 837, ff. 70-99.

57 AHN, CLERO SECULAR REGULAR, Libro 837, f.100.

58 AHN, CLERO_SECULAR_REGULAR, Libro 837, f.100.

59 AHN, CLERO_SECULAR_REGULAR, Libro 837, ff. 101-102.
} 
como Cristóbal Honorato el Viejo ${ }^{60}$ (para distinguirlo de su hijo Cristóbal Honorato el Mozo) era salmantino y desarrolló su actividad como escultor y ensamblador de retablos en Salamanca y Ávila. Está documentada una imagen de la Virgen que realizó en 1634 para la iglesia de Santa María del Berrocal correspondiente al término municipal de El Mirón cercana a Barco de Ávila. ${ }^{61}$ La imagen ha llegado a nuestros días.

En las cuentas de 1656 se recoge otro pago al escultor Cristóbal Onorato de 100 reales que completan el pago de la imagen de San José ${ }^{2}$. La imagen de San José que ocupa actualmente el retablo de la Hermandad de San José no se corresponde con el estilo de Cristóbal Honorato el Viejo sino con imaginería posterior.

Las cuentas del año 1657 recogen un gasto de 10 reales por "la mesa en que está el Santo" y otro de 46 reales por "un frontal" "63. En las cuentas de 1662 se incluye un pago de 12 reales al pintor Joseph Ciprés por "poner unos dedos al Niño Jesús y ponerle barniz ${ }^{64}$ ". Es importante resaltar que en 1664 se documenta un Miguel Ciprés, pintor y escultor al que se le encarga un frontal en lienzo para el altar y en 1666 dos pinturas para el retablo del santo. La coincidencia de los apellidos y la proximidad de las fechas permiten suponer su relación familiar (hermanos o padre/hijo).

En las cuentas de 1663 se recoge un pago de 160 reales a Juan Gómez ensamblador "a cuenta de los 480 en que está concertado el retablo por carta de pago que se entregó a Juan Hernández Bigotes, Mayordomo y a Juan Questas" "65. En las cuentas de 1664 figuran diversos cargos relativos al retablo de San José ${ }^{66}$ :

- 320 reales a Juan Gómez "que se debían por el retablo"

- 66 reales a Juan Gómez "por los días que se detuvo en asentarlo por haber diferencias sobre ello entre la Hermandad y el Cabildo" más 4 reales de "posada de cama que se le pagó".

- 4 reales para el letrado que consiguió la licencia del cabildo de la iglesia tras el pleito sobre dónde debía asentarse el retablo.

- 21 reales por la licencia anteriormente indicada.

- 16 reales para regalos entregados en la ciudad de Ávila y en el propio Barco de Ávila para la consecución de la licencia.

- 33 reales de clavos, cadenas y madera para el altar y banco en que se asentó.

- 24 reales por trasladar el retablo desde Navacepeda a la iglesia de la Asunción de Barco de Ávila.

60 RODRIGUEZ G. DE CEBALLOS, A.y CASASECA, A., "Escultores y ensambladores salmantinos de la segunda mitad del s. XVII", Boletín del Seminario de Estudios de Arte y Arqueología, 52 (1986), p.322. PARRADO DEL OLMO, J. M., "La colaboración entre ensambladores en los proyectos de retablos de finales del s. XVII y unas obras inéditas de Tomás de Sierra", Boletín del Seminario de Estudios de Arte y Arqueología, 62 (1996) p. 401.

61 RODRIGUEZ G. DE CEBAllos, A. y CASASECA, A., Op. cit, pp. 323- 324.

62 AHN, CLERO SECULAR REGULAR, Libro 837, f. 103.

63 AHN, CLERO SECULAR REGULAR, Libro 837, f. 105.

64 AHN, CLERO_SECULAR_REGULAR, Libro 837, f. 115.

65 AHN, CLERO_SECULAR_REGULAR, Libro 837, f. 118.

66 AHN, CLERO_SECULAR_REGULAR, Libro 837, f. 119. 
- 127 reales de "un frontal que hizo Ciprés, lienzo, bastidor y tachuelas" (se trata de Miguel Ciprés pues firma al final de las cuentas de este año).

- 9 reales que "costó una piedra para el altar de cantería” ${ }^{67}$.

Por tanto, en este año 1664, la cofradía gastó un total de 624 reales en el retablo sobre un total de gastos en ese año de 1155 reales. La partida correspondiente al retablo es la más importante, seguida por el gasto en cera para velas que ascendió a 328 reales. ${ }^{68}$ En este mismo año se registra además un gasto de 37 reales en "dos pares de candeleros". Estas cuentas de 1664, tan llenas de referencias a la obra artística del retablo están firmadas por el secretario de la Hermandad Juan Fernández Ribero, siendo Mayordomos Juan Francisco, carpintero y Domingo Hernández, hortelano. Los Mayordomos salientes, y por tanto responsables de estas cuentas eran Juan Cuesta, carpintero y Juan Sánchez Bigotes, hortelano.

No hay nada que destacar en las cuentas de 1665 y 1666 que solo recogen gastos ordinarios. En las cuentas aprobadas en abril de 1667 correspondientes a los ingresos y gastos del año 1666, se recoge, en el capítulo de ingresos, una derrama de 714 reales y medio para el dorado del retablo de San José ${ }^{69}$. La derrama se registra como "limosna que los hermanos dieron para dorar el retablo de S. Joseph". Recordemos que es en abril de 1666 cuando se firma el contrato con Miguel Ciprés para dorar el retablo y pintar los cuadros de los Desposorios y la Anunciación. Esta derrama se añade al pago anual de las cuotas que, en ese año de 1666, pagan los 93 hermanos de la cofradía y que asciende en total a 1029 reales.

En ese mismo año de 1667 se recogen varios pagos relativos al retablo ${ }^{70}$ :

- 1350 reales a Miguel Ciprés por dorar el retablo (recordemos que esta es la cantidad que aparece en el contrato con el artista transcrito anteriormente)

- 50 reales y medio a Miguel Ciprés por poner la cabeza al Niño Jesús y arreglar algunos defectos del retablo (se pagaron 26 reales en metálico y el resto en forma de 2 arrobas de vino).

- 67 reales a Miguel Ciprés de gastos menudos (tablas, clavos,...) para asentar el retablo, "como consta en su libro de caja".

- 26 reales y medio por una barra de hierro para guardapolvo del retablo.

Una vez cerradas las cuentas de este año 1667, con superávit como es habitual, se recoge un texto que detalla que se ha puesto un pleito a Miguel Ciprés por no haber cumplido las fechas indicadas en el contrato en su trabajo de dorado del retablo ${ }^{71}$. Las costas de ese pleito (procurador, escribano, letrado y diligencias) ascendieron a 868 reales. Si la cofradía cubrió estas costas es de suponer que perdió el pleito. Es remarcable que se gaste en pleitear casi un $70 \%$ del coste total del dorado del retablo.

\footnotetext{
67 AHN, CLERO_SECULAR_REGULAR, Libro 837, f. 120.

68 AHN, CLERO SECULAR REGULAR, Libro 837, f. 120.

69 AHN, CLERO SECULAR_REGULAR, Libro 837, f. 128.

70 AHN, CLERO_SECULAR_REGULAR, Libro 837, ff. 129 y 130.

71 AHN, CLERO_SECULAR_REGULAR, Libro 837, f. 130v.
} 


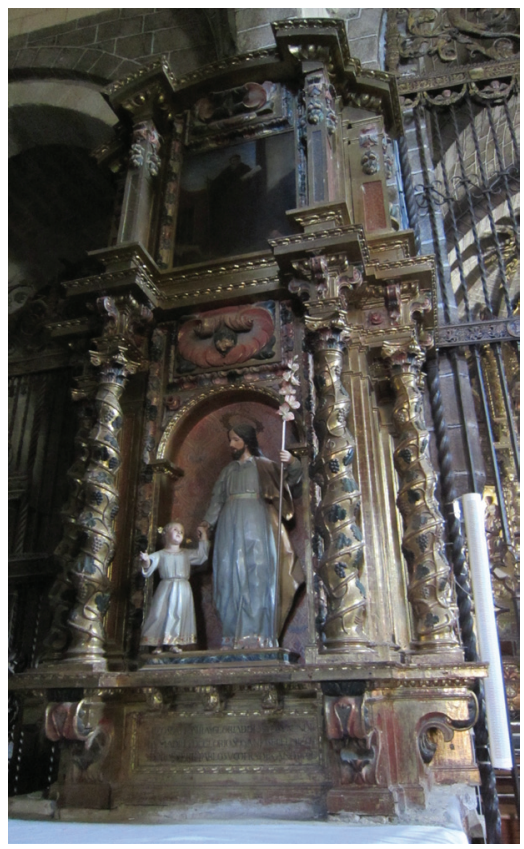

Fig. 9. Retablo de San José del entallador Juan del Arenal y los doradores Luis de Tobar y Antonio Fernández de Torres.

En las cuentas de 1668 se recoge un gasto de 49 reales y medio por "poner la cabeza del Niño Jesús" indicándose que el precio concertado era de 100 reales pero ya se cargaron 50 reales y medio en las cuentas del año anterior por lo que sólo restaban 49 reales y medio ${ }^{72}$. En las cuentas de 1671 figura un gasto de 69 reales "que se pagaron del ara que se trajo de Ávila con el porte, para el altar de San Joseph, para decir misa en él"73.

Parece que no fue suficiente este gasto para el altar de S. José porque al año siguiente, en las cuentas de 1672 se recoge un nuevo gasto de 71 reales y medio "que tuvo de costa poner una piedra para el altar de nuestro San Joseph, para una solera, con lo que costó el traerla que no se poder decir misa en él"74. Al final de estas cuentas de 1672 se recogen dos donaciones directas al retablo, una de 44 reales para el ara realizada por la mujer de Francisco Cabeza y otra de 10 reales para la diadema del Niño Jesús, del hortelano Gomar Zir.

En las cuentas de 1678 se registra un descargo de 3200 reales al entallador Juan del Arenal, vecino de Villafranca, por el retablo de madera y talla ${ }^{75}$. Es esta la primera in-

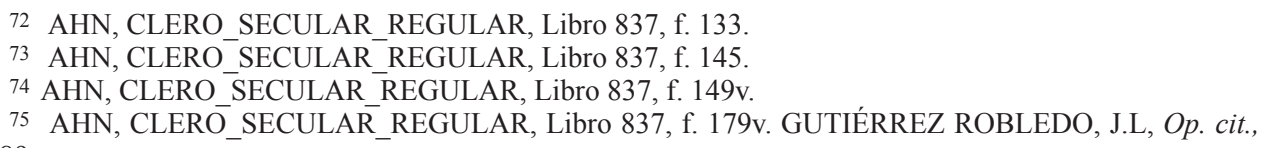




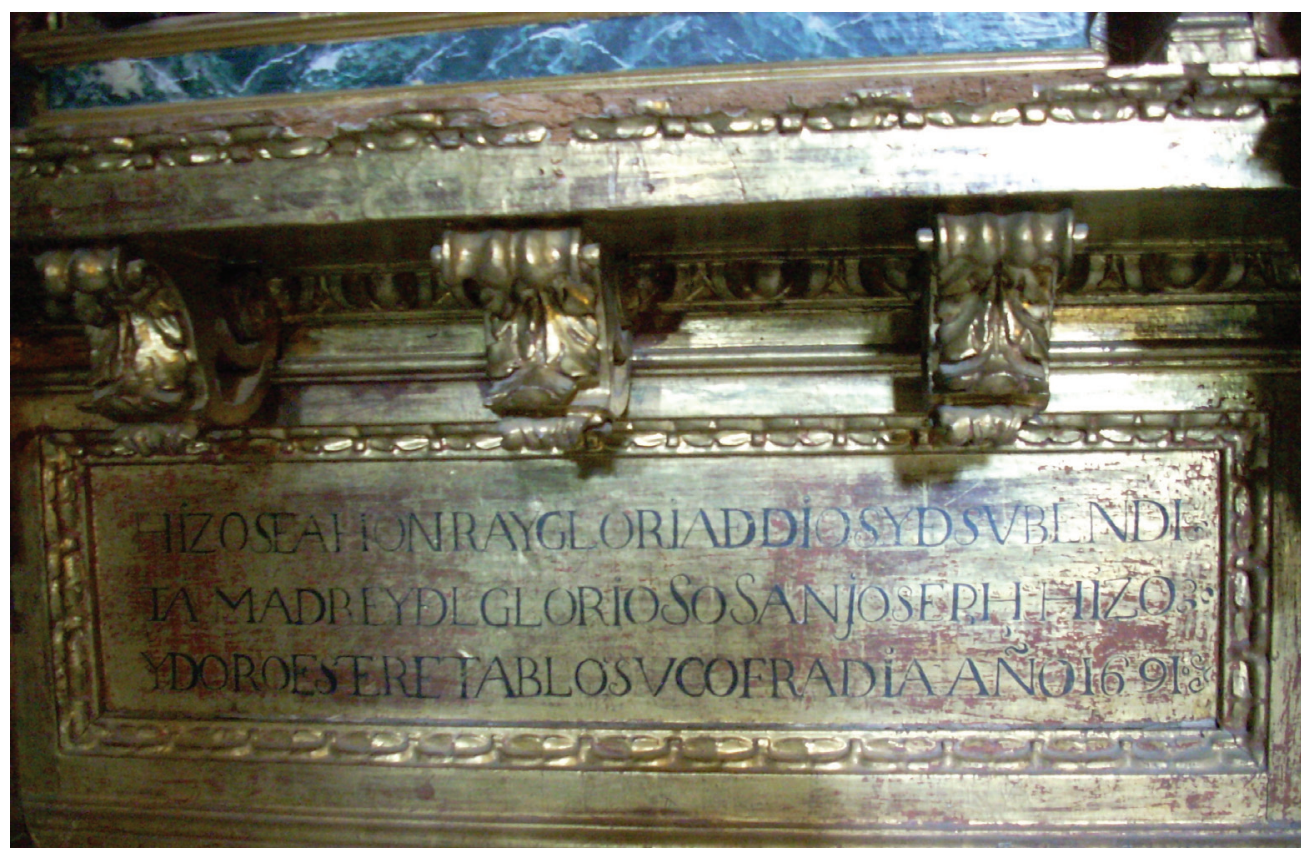

Fig. 10. De talle de la epigrafía conservada en la parte inferior del retablo de San José con su fecha de finalización en 1691. "Hizose a honra y gloria de Dios y de su bendita Madre y del glorioso San José. Hizo y doró este retablo su cofradía. Año 1691".

formación que tenemos del nuevo y definitivo retablo que se consagrará a San José, y que ha llegado hasta nosotros en su ubicación original [Fig.9]. Juan del Arenal (también llamado Juan de Arenas) fue un entallador de retablos muy activo en la provincia de Cáceres durante la segunda mitad del siglo XVII ${ }^{76}$. Está documentado también su trabajo en el retablo de la iglesia de Mamblas (Ávila) en $1678^{77}$.

Las cuentas de 1679 recogen un pago de 216 reales a Ventura por agrandar el cuadro de San Pedro que está en el retablo ${ }^{78}$ y que ha llegado a nuestros días en el ático del mismo [Fig. 9]. En las cuentas de 1685 figura un gasto de 24 reales a Luis de Tobar, dorador, "por cuenta del retablo del santo"79. Henos aquí frente al primer gasto registrado para dorar el nuevo retablo, el que se consagrará definitivamente a San José, patrón de la Hermandad. En las cuentas de 1686 figura un gasto de 156 reales por "dorar la vara del Santo, componer la corona de plata y hacer una nueva"

76 MÉNDEZ HERNÁN, V., "Precisiones sobre la obra del entallador Juan de Arenas en la provincia de Cáceres", Norba-Arte, XXV (2005) pp. 63-88.

77 VÁZQUEZ GARCÍA, F., El retablo barroco en las iglesias parroquiales de la zona norte de la provincia de Ávila, Madrid, 1991, p. 1138.

78 AHN, CLERO_SECULAR_REGULAR, Libro 837, f. 183v.

79 AHN, CLERO_SECULAR_REGULAR, Libro 837, f. 202r.

80 AHN, CLERO_SECULAR_REGULAR, Libro 837, f. 205 r. 
Esta corona de plata que se menciona pudiera ser una de las que se conservan en el museo parroquial de la iglesia de la Asunción.

Al final de estas cuentas de 1686 se registra la visita de D. Francisco Antonio de Bonilla, canónigo y visitador del obispado para revisar las cuentas. Después de aprobarlas demanda a los Mayordomos que en un máximo de cuatro meses terminen de dorar el retablo de San José pues, si no lo hacen, se les aplicará todo el rigor habitual (en otro texto se indica que es la pena de excomunión). No parece que el requerimiento de terminar el dorado del retablo en cuatro meses tuviera efecto porque los pagos finales del proceso de dorado se recogen cinco años después. El retablo se terminó de dorar en 1691 tal como figura en las cuentas aprobadas en abril de 1692. Este dato coincide con lo consignado en el epígrafe que figura en la parte baja del retablo y que reza así: "Hizose a honra y gloria de Dios y de su bendita Madre y del glorioso San José. Hizo y doró este retablo su cofradía. Año 1691" [Fig.10].

En las cuentas de 1691 se recoge un pago de 333 reales al dorador Antonio Fernández de Torres a cuenta de los 440 reales en que se contrató la finalización del dorado del retablo de San José ${ }^{81}$. Este maestro dorador, Antonio Fernández de Torres, con taller en Barco de Ávila, realizó después el dorado del retablo del altar mayor de la iglesia parroquial de Piedrahita, cuya ejecución había sido contratada a Manuel de Saldaña en ese mismo año de $1691^{82}$.

En las cuentas de 1692 se recoge un pago de 107 reales que se le debían al dorador del retablo Antonio Fernández de Torres para totalizar los 440 reales acordados. En el asiento se recoge que el retablo estaba terminado ${ }^{83}$ tal como consta en el epígrafe que figura en el retablo [Fig. 10]. En estas mismas cuentas de 1692 figura otro gasto de 9 reales pagados a Miguel Jorge por "componer los dedos del Niño Jesús"84.

\section{Consideraciones finales sobre los dos retablos documentados en el libro de la Hermandad de San José}

De todos los datos anteriormente citados se puede extraer la secuencia temporal y la autoría de dos de los retablos de la iglesia de la Asunción que han llegado hasta nosotros. El primero en el tiempo es el que hoy aloja la imagen de la Virgen de la Silla atribuida a Felipe Bigarny que está ubicado en la llamada capilla del Rosario, en el ábside lateral del lado de la Epístola de la iglesia de la Asunción [Figs. 6 y 7].

El retablo lo promovió la Hermandad de San José para ubicar en él la imagen de su santo patrón, tallada por Cristóbal Honorato el Viejo entre 1653 y 1655. La mazonería del retablo la realizó Juan Gómez entre 1662 y 1663 en la villa de Navacepeda de Tormes trasportando después el retablo a la iglesia de la Asunción. La Hermandad pagó un total de 1151 reales al ensamblador. En abril de 1666 se cerró un contrato por 1350 reales con el pintor y dorador Miguel Ciprés para que procediera a dorar el reta-

81 AHN, CLERO SECULAR_REGULAR, Libro 837, f. 215 r.

82 MÉNDEZ HERNÁN, V., Op.cit, p. 81.

83 AHN, CLERO_SECULAR_REGULAR, Libro 837, f. 218.

84 AHN, CLERO_SECULAR_REGULAR, Libro 837, f. 218v. 
blo y añadiera dos lienzos al óleo: unos Desposorios de la Virgen y una Anunciación de los que sólo nos ha llegado este último en los laterales del ático.

No sabemos exactamente la fecha en que se inicia el pleito entre la Hermandad de San José y el cabildo de la iglesia sobre el tema de la ubicación del retablo en la capilla del Rosario. Aunque no se cuenta con todos los detalles del pleito se conoce su resolución de septiembre de 1663 que obliga a la Hermandad a donar el retablo completo a la iglesia para ser reutilizado con otros fines.

El pleito perdido sobre este retablo hizo que la Hermandad de San José tuviera que acometer los pagos de un segundo retablo para San José que ha llegado hasta nosotros con una epigrafía que confirma los datos registrados en el libro de cuentas. El retablo, definitivamente consagrado a su patrón San José, está adosado al arco triunfal de acceso a la capilla mayor de la iglesia [Figs. 8 y 9]. La mazonería la realizó el entallador Juan del Arenal en 1678 y las tareas de dorado del mismo se iniciaron en 1685 por Luis de Tobar y se completaron en 1691 por Antonio Fernández de Torres.

En conclusión, los artistas contratados por la Hermandad de San José para realizar los dos retablos fueron el entallador Juan Gómez con taller en Navacepeda de Tormes y activo en 1662-63, el entallador Juan del Arenal, activo en 1678-85, el escultor Cristóbal Honorato el Viejo, activo en Barco de Ávila en 1653-55 y los doradores y pintores Miguel Ciprés, activo en Barco de Ávila en 1666, Luis de Tobar, activo en Barco de Ávila en 1685 y Antonio Fernández de Torres, activo en Barco de Ávila en 1691.

Es aún abundante la documentación por investigar relativa a las cofradías de la iglesia de la Asunción de Barco de Ávila que sin duda proporcionarán más información sobre los artistas y talleres locales.

\section{Bibliografía}

DE LA FUENTE ARRIMADAS, N., Fisiografía e historia del Barco de Ávila. Edición facsímil del original de 1926 realizado por José Luis Gutiérrez Robledo, Tomo I. Ávila, 1983.

FRANCO MATA, Á., "'Crucifixus dolorosus". Cristo crucificado, el héroe trágico del cristianismo bajomedieval, en el marco de la iconografía pasional, de la liturgia, mística y devociones" en Quintana, $\mathrm{n}^{\mathrm{o}} 1$ (2002), pp. 13-39.

GÓMEZ MORENO, M., Catálogo Monumental de la provincia de Ávila. Edición revisada y preparada por Aurea de la Morena y Teresa Pérez Higuera. Ávila, 1983.

GONZÁLEZ ZYMLA, H., "Arquitectura militar y urbanismo de frontera en Barco de Ávila”, Revista de Arqueología, 358 (2011), pp. 33-43.

GONZÁLEZ ZYMLA, H., Historia y arte en el real monasterio cisterciense de Santa María de Piedra, Tesis doctoral de la UCM, Tomo III, Madrid, 2011.

GUTIÉRREZ ROBLEDO, J.L., El Barco de Ávila: arquitectura y arte, Ávila, 2004. MÉNDEZ HERNÁN, V., "Precisiones sobre la obra del entallador Juan de Arenas en la provincia de Cáceres", Norba-Arte, vol. XXV (2005), pp. 63-88. 
PARRADO DEL OLMO, J.M., "La colaboración entre ensambladores en los proyectos de retablos de finales del s. XVII y unas obras inéditas de Tomás de Sierra", Boletín del Seminario de Estudios de Arte y Arqueología, 62 (1996), pp. 401-420.

RÉAU, L., Iconografía del arte cristiano, Tomo 2, Vol. 3, 4 y 5, Barcelona, 1997.

RODRIGUEZ G. DE CEBALLOS, A. y CASASECA, A., "Escultores y ensambladores salmantinos de la segunda mitad del s. XVII", Boletín del Seminario de Estudios de Arte y Arqueología, 52 (1986), pp. 321-342.

VÁZQUEZ GARCÍA, F., El retablo barroco en las iglesias parroquiales de la zona norte de la provincia de Ávila, Tesis doctoral de la UCM, Madrid, 1991.

\section{Documentos de Archivo}

AHN, CLERO_SECULAR_REGULAR, Libro 835: "Libro de caxa de las quentas y asiento de los gastos y censos que hecharon los oficiales de peine y carda de Señor San Severo desta villa del Varco. Hizose este año. 1628 años"

AHN, CLERO_SECULAR_REGULAR, Libro 837: "Libro de la hermandad del Glorioso S. Joseph, Esposo de la Madre de Dios Nuestro Señor que para gloria y honra de su divina Majestad fundaron los dos gremios de los carpinteros y hortelanos el año de 1653. En que están las ordenanzas, cabildos, cuentas y hermanos". 